\title{
IDENTIFIKASI PEMBEKALAN KETERAMPILAN ABAD 21 PADA ASPEK LITERASI TEKNOLOGI INFORMASI DAN KOMUNIKASI SISWA SMA NEGERI BENGKULU DALAM MATA PELAJARAN FISIKA
}

\author{
Annisatul Jannah*, Afrizal Mayub, Dedy Hamdani \\ Program Studi S1 Pendidikan Fisika, Jurusan Pendidikan MIPA \\ Fakultas Keguruan dan Ilmu Pendidikan Universitas Bengkulu \\ Jalan Raya Kandang Limun Bengkulu \\ e-mail ${ }^{*}$ : annisatuljannah9@gmail.com
}

\begin{tabular}{|l|c|c|c|} 
Diterima 15 Maret 2021 & Direvisi 13 Agustus 2021 & Disetujui 20 Agustus 2021 & Dipublikasikan 28 Agustus 2021
\end{tabular}
https://doi.org/10.33369/jkf.4.2.93-102

\begin{abstract}
ABSTRAK
Tujuan dari penelitian ini adalah untuk (1) Mendeskripsikan pem bekalan keterampilan abad 21 pada aspek keterampilan LTIK yang telah di berikan pada siswa menurut persepsi guru SMA kota Bengkulu dalam mata pelajaran fisika. (2) Mendeskripsikan pembekalan keterampilan abad 21 pada aspek keterampilan LTIK yang telah dilakukan guru menurut persepsi siswa SMA kota Bengkulu dalam mata pelajaran fisika. (3) Mendeskripsikan penguasaan keterampilan abad 21 pada aspek keterampilan LTIK yang dimiliki siswa menurut persepsi dirinya sendiri siswa SMA kota Bengkulu dalam mata pelajaran fisika. (4) Mendeskripsikan keterampilan abad 21 pada aspek keterampilan LTIK siswa menurut persepsi teman sebaya SMA kota Bengkulu dalam mata pelajaran fisika. Jenis yang penelitian ini adalah Descriptive Research. Sampel penelitian ini berjumlah 90 siswa dan 3 guru fisika dari 3 SMA yang berbeda di Kota Bengkulu. Teknik pengumpulan data yang digunakan dalam penelitian ini adalah kuesioner, wawancara dan observasi. Berdasarkan analisis data diperoleh pembekalan dan penguasaan keterampilan abad 21 pada aspek literasi teknologi informasi dan komunikasi siswa SMA Negeri Kota Bengkulu dalam mata pelajaran fisika menurut persepsi guru, dirinya sendiri dan teman sebaya berada pada kategori baik. Hasil yang diperoleh dapat dijadikan sebagai need assessment bagi penelitian RND (Reasearch And Development) seperti pengembangan media pembelajaran, modul pembelajaran model pembelajaran.

Kata Kunci: pembekalan, keterampilan abad 21, keterampilan literasi teknologi informasi dan komunikasi, pelajaran fisika, descriptive reasearch
\end{abstract}

\begin{abstract}
This reasearch has aimed to (1) to describe debriefing of $21^{\text {st }}$ century skills on aspects of LTIK skills that have been given to students according to the perceptions of Bengkulu city high school teachers in physics subjects. (2) to describe debriefing of $21^{\text {st }}$ century skills on aspects of LTIK skills that have been carried out by teachers according to the perceptions of Bengkulu city high school students in physics subjects. (3) describe the provision of 21st century skills in aspects of information and communication technology literacy skills possessed by students according to their own perception of bengkulu high school students in physics subjects. (4) describe the provision of $21^{\text {st }}$ century skills in aspects of LTIK skills that students have according to their own perceptions of high school students in Bengkulu City in physics. The type of research that this is Descriptive Research. The study sample was 90 students and 3 physics teachers from 3 high schools in the city of Bengkulu. Data collection techniques used in this study are questionnaires, interviews and observations. Based on data analysis, it was obtained and mastery by providing of 21 st century skills in the aspects of information and communication technology literacy for Bengkulu city high school students in physics according to teacher perceptions, themselves and their peers were in a good category. The results obtained can be used as a need assessment for RND (Reasearch And Development) research such as learning media development, learning model learning modules.
\end{abstract}

Keywords: debriefing, $21^{\text {st }}$ century skills, information and communication technology literacy skills, physics subjects, descriptive reasearch.

\section{PENDAHULUAN}

Pendidikan merupakan upaya manusia untuk memperluas pengetahuan dalam rangka membentuk nilai, sikap, dan perilaku. Pendidikan juga merupakan salah satu sarana untuk mengembangkan potensi diri dan keterampilan siswa melalui proses pembelajaran sebagai bekal 
bagi dirinya menjalani hidup bermasyarakat, berbangsa dan bernegara. Pendidikan adalah "Usaha sadar dan terencana untuk mewujudkan suasana belajar dan proses pembelajaran agar peserta didik secara aktif mengembangkan potensi dirinya untuk memiliki kekuatan spiritual keagamaaan, pengendalian diri, kepribadian, kecerdasan, akhlak mulia, serta keterampilan yang diperlukan dirinya, masyarakat, bangsa, dan negara"(1). Berdasarkan pengertian tersebut kita dapat memahami bahwa pendidikan adalah sebuah proses yang direncanakan sebelumnya, untuk menghasilkan pribadi yang dapat mengembangkan potensi dirinya.Pendidikan saat ini menghadapi tantangan baru, yaitu bagaimana menyiapkan sumber daya manusia yang memiliki keterampilan abad 21 . Sistem pendidikan harus diorientasikan pada pembekalan dan pengembangan keterampilan abad 21 pada peserta didik.

Saat ini paradigma pembelajaran telah bergeser dari pembelajaran konvensional menuju pembelajaran berbasis teknologi, khususnya teknologi informasi dan komunikasi. Pembelajaran berbasis teknologi memberikan ruang kepada pembelajar untuk memperoleh pengetahuan melalui berbagai sumber. Kenyataan ini menempatkan guru bukanlah sebagai satu-satunya sumber ilmu, melainkan pengetahuan dapat diperoleh dari manapun dengan kemudahan teknologi informasi dan komunikasi. Perkembangan teknologi informasi dan komunikasi yang semakin pesat telah mengubah cara mengajar pendidik dan cara belajar peserta didik. Banyak hal yang dirasa berbeda dengan proses pembelajaran sebelumnya, dimana pembelajaran terkini tidak dibatasi oleh ruang dan waktu untuk mendapatkan sumber belajar. Pilihan aplikasi yang tersedia sangat beragam untuk diterapkan dalam proses pembelajaran dan menawarkan wawasan-wawasan baru bagi peserta didik agar terdorong untuk menghasilkan informasi dan pengetahuan yang baru dengan cara yang inovatif (2).

Adapun kompetensi yang harus dimiliki guru adalah kompetensi pedagogik, kepribadian, sosial, dan profesional. Khususnya pengembangan kompetensi abad 21 terdapat keterampilanketerampilan yang diperlukan. Keterampilan yang dibutuhkan pada abad 21 meliputi kecakapan hidup dan berkarir, keterampilan belajar dan berinovasi dan keterampilan teknologi informasi dan komunikasi. Penerapan keterampilan abad 21 menuntut peserta didik untuk dapat meningkatkan kemampuan teknologi informasi dan komunikasi secara efektif dalam membangun pengetahuannya. Adapun materi pokok yang dapat dikembangkan dalam mata pelajaran abad 21 salah satunya mata pelajaran fisika.

Pembelajaran fisika di sekolah memiliki peran sentral dalam membekalkan keterampilan abad 21 peserta didik. Tujuan pembelajaran fisika yang tertuang di dalam konsep Kurikulum 2013 ialah menguasai konsep dan prinsip fisika, memiliki keterampilan mengembangkan pengetahuan dan sikap percaya diri sebagai bekal untuk melanjutkan pendidikan, serta sebagai bekal untuk mengembangkan ilmu pengetahuan dan iptek (3).

Tujuan tersebut memberikan penegasan bahwa pembelajaran fisika bukan hanya diorientasikan pada penguasaan pengetahuan dan sikap semata, tetapi jauh lebih penting ditujukan untuk mengembangkan aspek keterampilan peserta didik. Pada konsep pembelajaran abad 21, aspek keterampilan harus diorientasikan pada penguasaan keterampilan abad 21. Keterampilan ini sangat dibutuhkan agar peserta didik mampu menghadapi dan menyesuaikan diri dengan tantangan perkembangan zaman yang semakin kompleks.

Selain keempat keterampilan penting yang harus dikuasai pada abad ke-21 (berpikir kritis dan pemecahan masalah, kreativitas dan inovasi, kolaborasi, dan komunikasi), seseorang juga harus menguasai literasi teknologi informasi dan komunikasi. Negara-negara di dunia ini bahkan individu-individu di dunia ini merupakan bagian perekonomian global dan komunitas global. Keterkaitan ini membuatnya bahkan lebih mendesak bagi siswa di seluruh dunia untuk belajar bagaimana berkomunikasi, berkolaborasi, dan memecahkan masalah dengan masyarakat seluruh dunia (4). Literasi ini sangat penting bagi seseorang mengidentifikasi, menginvestigasi, memilih, mengatur, membuat, menyertakan, menilai mengkomunikasikan informasi secara baik dan legal dalam rangka membangun peserta didik yang berpengetahuan. Di lain pihak, berkaitan dengan literasi teknologi, seseorang harus mampu menggunakan teknologi untuk berkomunikasi di era digital sekarang. Semua keterampilan yang diperlukan oleh seseorang agar berhasil menghadapi

Identifikasi Pembekalan Keterampilan Abad 21 pada Aspek Literasi Teknologi Informasi dan Komunikasi Siswa SMA Negeri....

Annisatul Jannah*, Afrizal Mayub, Dedy Hamdani 
tantangan, kehidupan yang semakin kompleks dan penuh dengan ketidakpastian, serta agar berhasil dalam hidup dan karir di dunia kerja merupakan keterampilan abad ke-21. Seseorang tidak memiliki keterampilan ini sejak lahir, melainkan keterampilan ini diperoleh dari proses latihan, belajar, atau pengalaman (5).

Keterampilan-keterampilan penting di abad ke-21 masih relevan dengan empat pilar kehidupan yang mencakup learning to know, learning to do, learning to be dan learning to live together. Empat prinsip tersebut masing-masing mengandung keterampilan khusus yang perlu diberdayakan dalam kegiatan belajar, seperti keterampilan khusus yang perlu di berdayakan dalam kegiatan belajar seperti keterampilan berfikir kritis, memecahkan masalah, metakognisi, keterampilan berkomunikasi, berkolaborasi, inovasi dan kreasi, literasi informasi, dan berbagai keterampilan lainnya (6).

Literasi Teknologi informasi dan komunikasi merupakan keterampilan penting agar dapat berpartisipasi secara penuh dalam masyarakat. Penggunaan Teknologi informasi dan komunikasi dalam kegiatan pembelajaran dipandang perlu agar Pendidikan tetap relevan dengan abad ke-21. Kemampuan yang terdiri dari aspek ilmu pengetahuan, keterampilan, berpikir kritis, serta pembuatan keputusan dalam upaya pemanfaatan teknologi atau inovasi hasil karya manusia secara efektif khususnya pada dunia pendidikan dapat mendorong cara berpikir yang lebih kritis dan inovatif. Literasi teknologi informasi dan komunikasi peserta didik dapat diukur melalui angket persepsi yang diberikan kepada peserta didik (2).

Era revolusi 4.0 merupakan tantangan berta bagi guru indonesia. Dimana hal paling penting yang harus diperhatikan untuk menghadapi tantangan era digital ini dalam bidang pendidikan. Seorang guru pada zaman ini harus melek teknologi mengingat kualitas guru yang hampa akan teknologi tidak mampu menanamkan "daya kritis" kepada murid untuk menjadi manusia revoluioner. Sehingga mereka terhambat untuk menggali potensi dirinya. "Pentingnya literasi teknologi informasi dan komunikasi bagi guru sekolah dasar untuk menyiapkan generasi milenial" berdasarkan penelitian yang telah dilakukan dimana hal penting yang harus diperhatikan untuk menghadapi tantangan era digital ini dalam bidang pendidikan. Seorang guru pada zaman ini harus melek teknologi mengingat kualitas guru yang hampa akan teknologi tidak akan mampu menanamkan " daya kritis" menggali potensi dirinya (7). Eksplorasi Literasi Teknologi Informasi dan Komunikasi Siswa melalui Blended Learning Fisika" berdasarkan penelitian yang telah dilakukan diperoleh bahwa Literasi Teknologi Informasi dan Komunikasi siswa cenderung identik satu sama lain serta meningkat pada tiap pertemuan pembelajaran (8). Untuk menghadapi tantangan di era globalisasi dan kebutuhan literasi baru revolusi 4.0 dan menyelesaikan persoalan perubahan kurikulum pembelajaran TIK maka sangat dibutuhkan pengembangannya (9). Pendapat guru dan siswa tentang manfaat Teknologi Informasi dan Komunikasi khususnya edukasi net antara lain: (1) memudahkan guru dan siswa dalam mencari sumber belajar alternatif; (2 ) bagi siswa, dapat memperjelas materi yang telah disampaikan oleh guru, karena disamping disertai gambar juga ada animasi menarik; (3) cara belajar lebih efisien; (4) menambah wawasan; (5) mengetahui dan mengikuti perkembangan materi dan info-info lain yang berhubungan dengan bidang studi; dan (6) membantu siswa melek ICT (10).

Dalam kamus besar Indonesia Persepsi adalah tanggapan atau penerimaan langsung dari sesuatu. Persepsi adalah kemampuan membedakan suatu benda dengan benda yang lainnya, mengelompokkan benda-benda yang berdekatan atau dapat memfokuskan perhatiannya dalam suatu objek dengan memberikan makna melalui stimuli inderawi (11). Persepsi merupakan proses kognitif seseorang dalam memahami lingkungannya baik lewat penglihatan, pendengaran, penghayatan, perasaan, dan penciuman. Berdasarkan pengertian diatas dapat kita simpulkan bahwa persepsi ialah tanggapan seorang individu terhadap suatu objek atau subjek yang dihasilkan saat individu tersebut sedang atau sudah berikteraksi dengan subjek atau objeknya melalui inderanya (12). Terdapat tiga aspek yang dapat membangun sebuah persepsi, yaitu: (a)Komponen kognitif (perseptual), yaitu komponen yang berhubungan dengan pengetahuan, pandangan, dan keyakinan seseorang terhadap sebuah objek, (b) komponen afektif (emosional), yaitu komponen yang berkaitan rasa senang yang positif atau tidak senang yang negatif pada suatu objek, dan (c) 
komponen konatif (perilaku), yaitu komponen yang berkaitan dengan kecenderungan seseorang dalam bertindak terhadap suatu objek (13).

Maka perlu diidentifikasi pembekalan keterampilan literasi teknologi informasi dan komunikasi yang telah dilakukan oleh guru dan siswa dimana perlu kita ketahui bahwa keterampilan literasi teknologi informasi dan komunikasi adalah suatu kemampuan untuk menggunakan teknologi dalam proses pembelajaran untuk mencapai kecakapan berpikir dan belajar peserta didik (14).

Berdasarkan uraian yang telah dipaparkan, maka dilakukan penelitian yang berjudul "Identifikasi Pembekalan Keterampilan Abad 21 Pada Aspek Literasi Teknologi Informasi dan Komunikasi Siswa SMA Kota Bengkulu Dalam Mata Pelajaran Fisika". Adapun tujuan penelitian adalah sebagai berikut : (1) Mendeskripsikan pembekalan keterampilan abad 21 pada aspek keterampilan LTIK yang telah di berikan pada siswa menurut persepsi guru SMA kota Bengkulu dalam mata pelajaran fisika, (2) Mendeskripsikan pembekalan keterampilan abad 21 pada aspek keterampilan LTIK yang telah dilakukan guru menurut persepsi siswa SMA kota Bengkulu dalam mata pelajaran fisika, (3) Mendeskripsikan penguasaan keterampilan abad 21 pada aspek keterampilan LTIK yang dimiliki siswa menurut persepsi dirinya sendiri siswa SMA kota Bengkulu dalam mata pelajaran fisika dan (4) Mendeskripsikan keterampilan abad 21 pada aspek keterampilan LTIK siswa menurut persepsi teman sebaya SMA kota Bengkulu dalam mata pelajaran fisika.

\section{METODE PENELITIAN}

Penelitian ini tergolong penelitian deskriptif (descriptive research) yaitu penelitian yang dilakukan untuk menggambarkan atau menjelaskan secara sistematis, faktual, dan akurat mengenai fakta dan sifat populasi tertentu (15). Responden dalam penelitian ini adalah 90 siswa SMA yang berasal dari 3 SMA di Kota Bengkulu dan 3 orang guru fisika. Instrumen yang digunakan dalam penelitian ini berupa lembar angket siswa dan lembar wawancara guru yang telah diuji validitas dan reabilitasnya. Analisis data dalam penelitian ini dilakukan pada saat pengumpulan data berlangsung dan setelah selesai pengumpulan dalam periode tertentu.

Analisis data kualitatif dilakukan secara interaktif dan berlangsung secara terus menerus sampai tuntas sehingga datanya sudah jenuh. Aktivitas dalam analisis data, yaitu data reduction, data display, dan conclusion drawing/verification (15). Analisis data angket menggunakan skala likert dengan memberikan skor pada masing-masing jawaban pertanyaan alternatif sebagai berikut:

\begin{tabular}{cc} 
Tabel 1. Alternatif Jawaban Dengan Skala Likert \\
\hline Keterangan & Skala \\
\hline Sangat Setuju (SS) & 5 \\
Setuju (S) & 4 \\
Kurang Setuju (KS) & 3 \\
Tidak Setuju (TS) & 2 \\
Sangat Tidak Setuju & 1
\end{tabular}

(STS)

Setelah data angket telah terkumpul, kemudian dilakukan pengolahan data dan disajikan dalam bentuk tabel dan dianalisis. Pada penelitian ini, peneliti menggunakan analisis deskriptif yang dilakukan pengklasifikasian terhadap jumlah total skor responden. Dari jumlah skor jawaban responden yang diperoleh kemudian disusun kriteria penilaian untuk setiap item pernyataan. Untuk menjawab deskripsi tentang masing-masing variabel penelitian, maka digunakan rentang kriteria penilaian sebagai berikut :

$$
P=\frac{\text { Rancangan }}{\text { Banyak Kelas }}
$$


P merupakan panjang kelas interval, rentang adalah data angket terbesar - data terkecil, dan banyak kelas adalah 3. Menetapkan peringkat dalam setiap variabel penelitian dapat dilihat dari perbandingan antara skor aktual dengan skor ideal, kecenderungan jawaban responden didasarkan pada nilai rata-rata skor jawaban yang selanjutnya dikategorikan pada rentang skor berikut ini: skor minimum adalah 1 dan skor maksimum adalah 5, sedangkan lebar skala $=1,33$ dengan demikian kategori skala dilihat pada tabel 2.

Tabel 2. Kategori Skala Skala

\begin{tabular}{cc}
\hline Skala & Kategori \\
\hline $1,00-2,33$ & Kurang \\
$2,34-3,66$ & Cukup \\
$3,67-5$ & Baik \\
\hline
\end{tabular}

Data angket dikategorikan berdasarkan tabel 2. Selanjutnya, dilakukan triangulasi pada data yang diperoleh yakni dianalisis secara deskriptif untuk mendapatkan informasi yang dibutuhkan.

\section{HASIL DAN PEMBAHASAN}

Penelitian dilakukan di tiga SMA Negeri kota Bengkulu yaitu SMA Negeri 2 Kota Bengkulu, SMA Negeri 6 Kota Bengkulu, dan SMA Negeri 8 Kota Bengkulu. Eksplorasi pembekalan siswa terhadap keterampilan abad 21 dilakukan dengan menggunakan lembar angket persepsi siswa dan lembar wawancara guru, melibatkan 90 siswa MIPA SMA kelas X, XI, dan kelas XII sebagai responden yang berasal dari 3 SMA Negeri Kota Bengkulu dan 3 orang guru fisika. Angket persepsi siswa terhadap pembekalan keterampilan abad 21 pada aspek keterampilan LTIK terdiri atas 8 indikator yaitu I1 (Mengidentifikasi informasi), I2 (Menginvestigasi informasi), I3 (Memilih informasi), I4 (Mengatur informasi), I5 (Membuat informasi), I6 (Menyertakan informasi), I7 (Menilai informasi), dan I8 (Mengomunikasikan informasi).

\subsection{Pembekalan Keterampilan Abad 21 Pada Aspek Keterampilan LTIK Yang Telah Diberikan pada siswa menurut guru SMA Kota Bengkulu}

Keterampilan literasi teknologi informasi dan komunikasi merupakan keterampilan yang harus dibekalkan pada siswa pada abad 21 ini. Pembekalan keterampilan abad 21 pada aspek literasi teknologi informasi dan komunikasi yang telah diberikan pada siswa menurut guru SMA Kota Bengkulu sudah bisa dikategorikan baik ini dapat dilihat dari hasil wawancara yang telah dilakukan dengan 3 guru fisika SMA Kota Bengkulu. Dari hasil wawancara didapatkan bahwa pada pembelajaran sering dilakukan dengan menggunakan internet karena sekarang proses pembelajaran melalui daring jadi siswa lebih sering menggunakan internet dalam proses pembelajaran. Kemampuan siswa mencari informasi menggunakan internet pada pembelajaran fisika bisa dikatakan sangat mampu karena siswa zaman sekarang lebih pintar dari pada gurunya dalam mencari informasi di internet. Kompetensi dalam menguasi IT nya lebih bagus. Dan siswa lebih cepat mencari jawaban soal-soal yang diberikan oleh guru melalui internet. Apalagi pelajaran fisika lebih mudah menggunakan internet karena banyak sekali video-video di internet yang isinya meterimateri fisika. Kemampuan siswa dalam belajar menggunakan internet bisa di kategorikan baik. Siswa menguasai internet dengan baik, baik itu dari istilah-istilah yang ada dalam penggunakan intermet, dalam hal membuat akun, mencari materi sampai mengentri data siswa sudah bisa di kategorikan baik.

\subsection{Persepsi Siswa Terhadap Pembekalan Keterampilan Abad 21 Pada Aspek Keterampilan LTIK Yang telah diberikan guru}

Angket ini merupakan angket yang ditujukan untuk siswa menyatakan pendapat apakah guru telah memberikan pembekalan keterampilan abad 21 pada aspek keterampilan LTIK. Berikut hasil angket persepsi siswa terhadap pembekalan keterampilan abad 21 pada aspek keterampilan LTIK. 


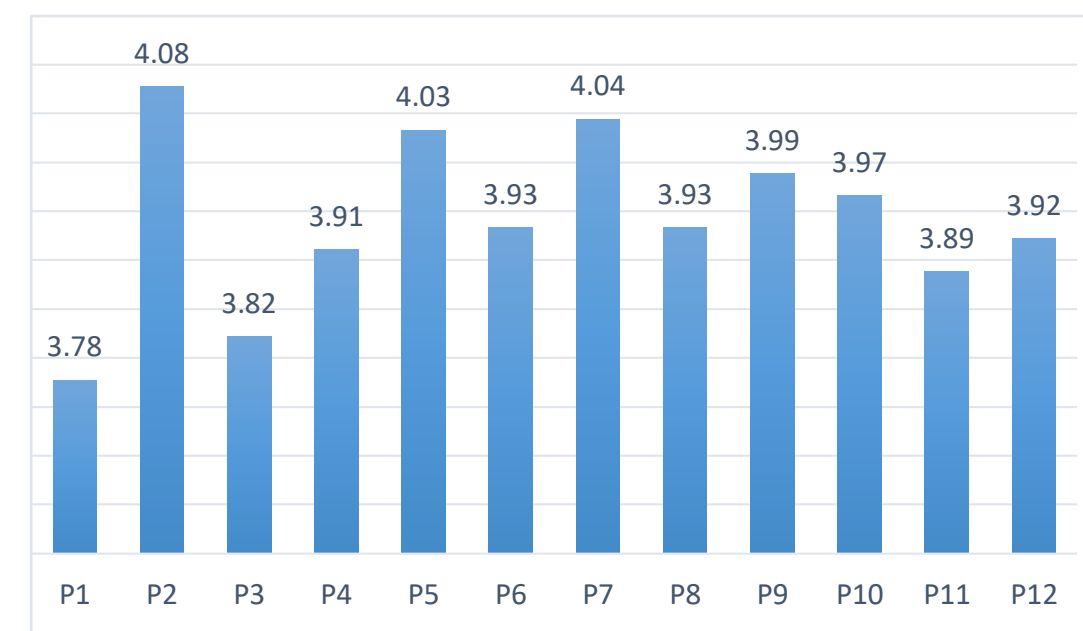

Gambar 1. Persepsi Siswa terhadap Pembekalan Keterampilan LTIK

Berdasarkan Gambar 1, hasil analisis data angket setiap butir dalam kategori Baik. Adapun skor rata-rata setiap indikator pembekalan keterampilan LTIK siswa dapat dilihat pada tabel 3.

Tabel 3. Persepsi siswa terhadap pembekalan keterampilan LTIK

\begin{tabular}{lcc}
\hline \multicolumn{1}{c}{ Indikator Keterampilan } & Skor Rata-rata & Kategori \\
\hline Mengidentifikasi Informasi & 3,78 & Baik \\
Menginvestigasi Informasi & 3,95 & Baik \\
Memilih Informasi & 3,91 & Baik \\
Mengatur Informasi & 4,03 & Baik \\
Membuat Informasi & 3,93 & Baik \\
Menyertakan Informasi & 3,99 & Baik \\
Menilai Informasi & 3,98 & Baik \\
Mengkomukasikan Informasi & 3,91 & Baik \\
Skor rat-rata & $\mathbf{3 , 9 4}$ & Baik \\
\hline
\end{tabular}

Tabel 3 menunjukkan skor persepsi siswa pada indikator yaitu Mengidentifikasi informasi (I1) yang didapat berada pada kategori baik dengan rata-rata skor 3,78. Dilihat dari hasil data angket bahwa guru telah membekali keterampilan abad 21 pada aspek LTIK dengan mengajarkan siswa representasi dari materi yang dipelajar. Persepsi siswa terhadap menginvestigasi informasi (I2) yang didapat berada pada kategori baik dengan rata-rata skor 3,95. Dilihat dari hasil data angket bahwa guru telah membekali keterampilan abad 21 pada aspek LTIK dengan mengajarkan siswa mencari berbagai sumber belajar yang ada diinternet. Indikator memilih informasi (I3) yang didapat berada pada kategori baik dengan rata-rata skor 3,91. Dilihat dari hasil data angket bahwa guru telah membekali keterampilan abad 21 pada aspek LTIK dengan mengajarkan siswa sumber informasi pembelajaran yang tepat. Persepsi siswa terhadap mengatur informasi (I4) yang didapat berada pada kategori baik dengan rata-rata skor 4,03. Dilihat dari hasil data angket bahwa guru telah membekali keterampilan abad 21 pada aspek LTIK dengan mengajarkan siswa mensistesa informasi pembelajaran dari berbagai sumber yang ada. Indikator membuat informasi (I5) yang didapat berada pada kategori baik dengan rata-rata skor 3,93. Dilihat dari hasil data angket bahwa guru telah membekali keterampilan abad 21 pada aspek LTIK dengan mengajarkan siswa menuntaskan format belajar. Persepsi siswa terhadap menyertakan informasi (I6) yang didapat berada pada kategori baik dengan rata-rata skor 3,99. Dilihat dari hasil data angket bahwa guru telah membekali keterampilan abad 21 pada aspek LTIK dengan mengajarkan siswa mempertimbangkan apa yang telah dilakukan untuk hasil belajar lebih baik dari sebelumnya. Indikator menilai informasi (I7) yang didapat berada pada kategori baik dengan rata-rata skor 3,98. Dilihat dari hasil data angket bahwa guru telah membekali keterampilan abad 21 pada aspek LTIK dengan mengajarkan siswa mempertimbangkan apa yang telah dilakukan untuk hasil belajar lebih baik dari sebelumnya. Indikator mengomunikasikan informasi (I8) yang didapat berada pada 
kategori baik dengan rata-rata skor 3,91. Hasil data angket menunjukan bahwa guru telah mengajarkan siswa hasil belajar dalam bentuk portofolio dan siswa juga sudah mampu menyerahkan portofolio kepada guru untuk memperoleh justifikasi atas kinerja.

\subsection{Persepsi Siswa Terhadap Penguasaan Keterampilan Abad 21 Pada Aspek Keterampilan LTIK Yang Dimiliki Siswa}

Angket ini merupakan angket yang ditujukan untuk siswa menyatakan pendapat apakah siswa telah menguasai keterampilan abad 21 pada aspek keterampilan LTIK. Berikut hasil angket persepsi siswa terhadap penguasaan keterampilan abad 21 pada aspek keterampilan LTIK.

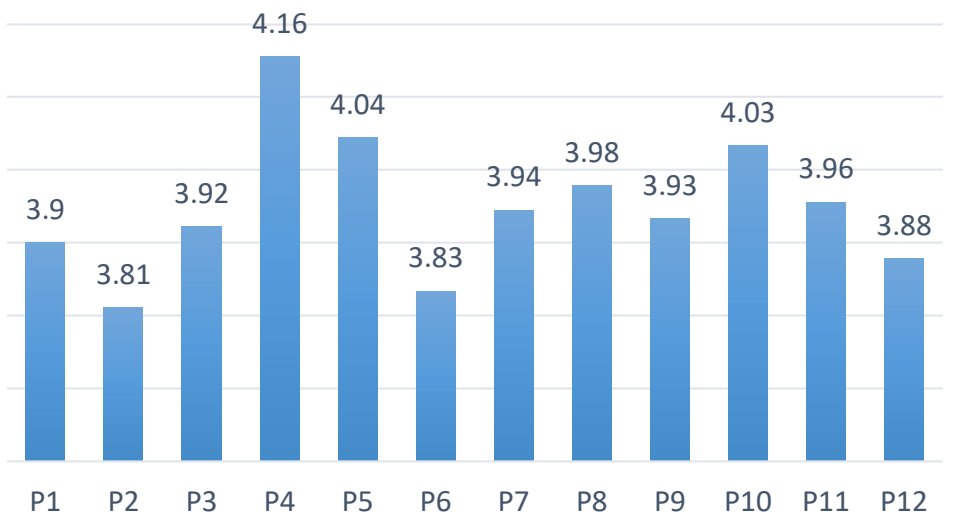

Gambar 2. Persepsi Siswa terhadap Penguasaan Keterampilan LTIK

Berdasarkan Gambar 2, hasil analisis data angket setiap butir dalam kategori Baik. Adapun skor rata-rata setiap indikator penguasaan keterampilan LTIK siswa dapat dilihat pada tabel 4.

Tabel 4. Persepsi siswa terhadap penguasaan keterampilan LTIK

\begin{tabular}{lcc}
\hline \multicolumn{1}{c}{ Indikator Keterampilan } & Skor Rata-rata & Kategori \\
\hline Mengidentifikasi Informasi & 3,9 & Baik \\
Menginvestigasi Informasi & 3,87 & Baik \\
Memilih Informasi & 4,16 & Baik \\
Mengatur Informasi & 3,04 & Baik \\
Membuat Informasi & 3,83 & Baik \\
Menyertakan Informasi & 3,96 & Baik \\
Menilai Informasi & 3,98 & Baik \\
Mengkomukasikan Informasi & 3,92 & Baik \\
Skor rat-rata & $\mathbf{3 , 9 5}$ & Baik \\
\hline
\end{tabular}

Tabel 4 menunjukkan skor persepsi siswa pada indikator yaitu Mengidentifikasi informasi (I1) yang didapat berada pada kategori baik dengan rata-rata skor 3,9. Dilihat dari hasil data angket bahwa guru telah membekali keterampilan abad 21 pada aspek LTIK dengan mengajarkan siswa representasi dari materi yang dipelajar. Persepsi siswa terhadap menginvestigasi informasi (I2) yang didapat berada pada kategori baik dengan rata-rata skor 3,87. Dilihat dari hasil data angket bahwa guru telah membekali keterampilan abad 21 pada aspek LTIK dengan mengajarkan siswa mencari berbagai sumber belajar yang ada diinternet. Indikator memilih informasi (I3) yang didapat berada pada kategori baik dengan rata-rata skor 4,16. Dilihat dari hasil data angket bahwa guru telah membekali keterampilan abad 21 pada aspek LTIK dengan mengajarkan siswa sumber informasi pembelajaran yang tepat. Persepsi siswa terhadap mengatur informasi (I4) yang didapat berada pada kategori baik dengan rata-rata skor 3,04.

Dilihat dari hasil data angket bahwa guru telah membekali keterampilan abad 21 pada aspek LTIK dengan mengajarkan siswa mensistesa informasi pembelajaran dari berbagai sumber yang ada. Indikator membuat informasi (I5) yang didapat berada pada kategori baik dengan rata-rata skor 3,83. Dilihat dari hasil data angket bahwa guru telah membekali keterampilan abad 21 pada aspek LTIK dengan mengajarkan siswa menuntaskan format belajar. Persepsi siswa terhadap menyertakan 
informasi (I6) yang didapat berada pada kategori baik dengan rata-rata skor 3,96. Dilihat dari hasil data angket bahwa guru telah membekali keterampilan abad 21 pada aspek LTIK dengan mengajarkan siswa mempertimbangkan apa yang telah dilakukan untuk hasil belajar lebih baik dari sebelumnya. Indikator menilai informasi (I7) yang didapat berada pada kategori baik dengan ratarata skor 3,98. Dilihat dari hasil data angket bahwa guru telah membekali keterampilan abad 21 pada aspek LTIK dengan mengajarkan siswa mempertimbangkan apa yang telah dilakukan untuk hasil belajar lebih baik dari sebelumnya. Indikator mengomunikasikan informasi (I8) yang didapat berada pada kategori baik dengan rata-rata skor 3,92. Hasil data angket menunjukan bahwa guru telah mengajarkan siswa hasil belajar dalam bentuk portofolio dan siswa juga sudah mampu menyerahkan portofolio kepada guru untuk memperoleh justifikasi atas kinerja.

\subsection{Persepsi Teman Sebaya Terhadap Keterampilan Abad 21 Pada Aspek Keterampilan LTIK Yang Telah Dibekalkan}

Sasaran dari angket ini adalah untuk siswa menyatakan pendapat apakah teman sebaya telah menguasai keterampilan abad 21 pada aspek keterampilan LTIK. Berikut hasil angket persepsi teman sebaya terhadap keterampilan abad 21 pada aspek keterampilan LTIK. Berikut hasil angket tersebut.

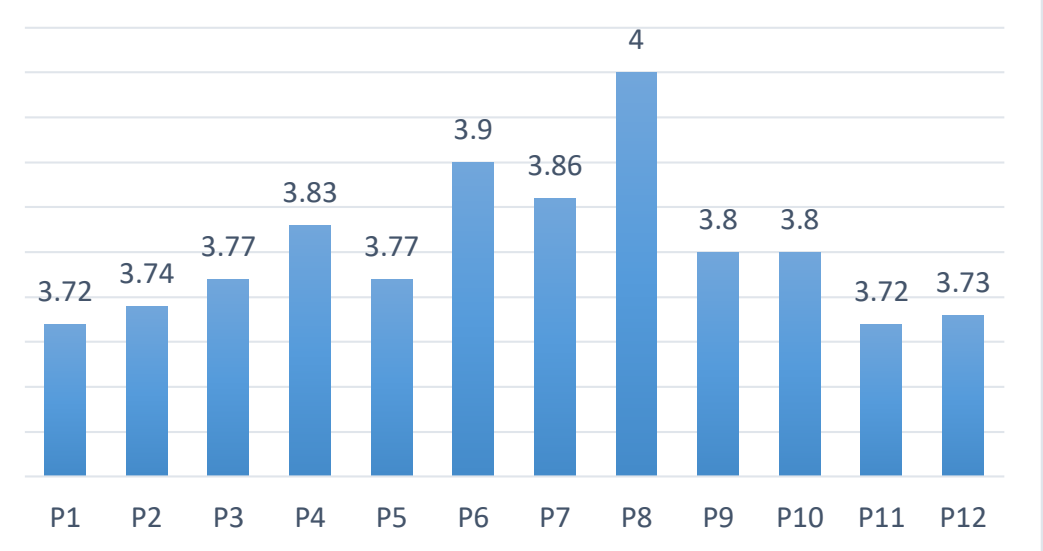

Gambar 3. Persepsi Teman Sebaya terhadap Keterampilan LTIK

Berdasarkan Gambar 3, hasil analisis data angket setiap butir dalam kategori Baik. Adapun skor rata-rata setiap indikator keterampilan LTIK siswa dapat dilihat pada tabel 5.

Tabel 5. Persepsi Teman Sebaya terhadap Keterampilan LTIK

\begin{tabular}{lcc}
\hline \multicolumn{1}{c}{ Indikator Keterampilan } & Skor Rata-rata & Kategori \\
\hline Mengidentifikasi Informasi & 3,72 & Baik \\
Menginvestigasi Informasi & 3,76 & Baik \\
Memilih Informasi & 3,83 & Baik \\
Mengatur Informasi & 3,77 & Baik \\
Membuat Informasi & 3,90 & Baik \\
Menyertakan Informasi & 3,93 & Baik \\
Menilai Informasi & 3,80 & Baik \\
Mengkomukasikan Informasi & 3,73 & Baik \\
Skor rata-rata & $\mathbf{3 , 8 1}$ & Baik \\
\hline
\end{tabular}

Tabel 5 menunjukkan skor persepsi siswa pada indikator yaitu Mengidentifikasi informasi (I1) yang didapat berada pada kategori baik dengan rata-rata skor 3,72. Dilihat dari hasil data angket bahwa guru telah membekali keterampilan abad 21 pada aspek LTIK dengan mengajarkan siswa representasi dari materi yang dipelajar. Persepsi teman sebaya terhadap menginvestigasi informasi (I2) yang didapat berada pada kategori baik dengan rata-rata skor 3,76. Dilihat dari hasil data angket bahwa guru telah membekali keterampilan abad 21 pada aspek LTIK dengan mengajarkan siswa mencari berbagai sumber belajar yang ada diinternet. Indikator memilih informasi (I3) yang didapat berada pada kategori baik dengan rata-rata skor 3,83. Dilihat dari hasil 
data angket bahwa guru telah membekali keterampilan abad 21 pada aspek LTIK dengan mengajarkan siswa sumber informasi pembelajaran yang tepat. Persepsi teman sebaya terhadap mengatur informasi (I4) yang didapat berada pada kategori baik dengan rata-rata skor 3,77. Dilihat dari hasil data angket bahwa guru telah membekali keterampilan abad 21 pada aspek LTIK dengan mengajarkan siswa mensistesa informasi pembelajaran dari berbagai sumber yang ada. Indikator membuat informasi (I5) yang didapat berada pada kategori baik dengan rata-rata skor 3,90. Dilihat dari hasil data angket bahwa guru telah membekali keterampilan abad 21 pada aspek LTIK dengan mengajarkan siswa menuntaskan format belajar. Persepsi teman sebaya terhadap menyertakan informasi (I6) yang didapat berada pada kategori baik dengan rata-rata skor 3,93. Dilihat dari hasil data angket bahwa guru telah membekali keterampilan abad 21 pada aspek LTIK dengan mengajarkan siswa mempertimbangkan apa yang telah dilakukan untuk hasil belajar lebih baik dari sebelumnya. Indikator menilai informasi (I7) yang didapat berada pada kategori baik dengan ratarata skor 3,80. Dilihat dari hasil data angket bahwa guru telah membekali keterampilan abad 21 pada aspek LTIK dengan mengajarkan siswa mempertimbangkan apa yang telah dilakukan untuk hasil belajar lebih baik dari sebelumnya. Indikator mengomunikasikan informasi (I8) yang didapat berada pada kategori baik dengan rata-rata skor 3,73. Hasil data angket menunjukan bahwa guru telah mengajarkan siswa hasil belajar dalam bentuk portofolio dan siswa juga sudah mampu menyerahkan portofolio kepada guru untuk memperoleh justifikasi atas kinerja.

\section{SIMPULAN DAN SARAN \\ 4.1 Simpulan}

Berdasarkan hasil analisis data dan pembahasan yang telah dilakukan disimpulkan bahwa 1) Pembekalan keterampilan abad 21 pada aspek keterampilan LTIK yang telah di berikan pada siswa SMA kota Bengkulu dalam mata pelajaran fisika menurut persepsi guru pada kategori baik. 2) Pembekalan keterampilan abad 21 pada aspek keterampilan LTIK yang telah dilakukan guru SMA kota Bengkulu dalam mata pelajaran fisika dengan skor rata-rata 3,94 berada pada kategori baik. 3) Penguasaan keterampilan abad 21 pada aspek keterampilan LTIK yang dimiliki siswa menurut persepsi dirinya sendiri siswa SMA kota Bengkulu dalam mata pelajaran fisika dengan skor ratarata 3,95 berada pada kategori baik. 4) Keterampilan abad 21 pada aspek keterampilan LTIK siswa menurut persepsi teman sebaya SMA kota Bengkulu dalam mata pelajaran fisika dengan skor ratarata 3,80 berada pada kategori baik.

\subsection{Saran}

Berdasarkan penelitian yang sudah dilakukan, disarankan beberapa hal, yakni 1) Guru harus lebih membekali siswa dengan keterampilan abad 21 pada aspek keterampilan literasi teknologi informasi dan komunikasi pada setiap indikator dengan teliti. 2) Data hasil penelitian dapat dijadikan need assessment untuk RND (Research And Development) maka perlu dilakukan penelitian RND seperti pengembangan media, dan model pembelajaran. 3) Perlu dilakukan lebih lanjut tentang pembekalan keterampilan abad 21 pada aspek keterampilan belajar dan berinovasi, dan keterampilan hidup dan berkarir.

\section{UCAPAN TERIMA KASIH}

Penulis mengucapkan terima kasih kepada dosen yang telah membimbing dalam penulisan artikel ini. Terima kasih kepada siswa dan guru SMAN Kota Bengkulu yang telah menjadi bagian dari proses penelitian dan pihak lain yang telah membantu.

\section{DAFTAR PUSTAKA}

1. Indonesia R. UU No 20 Tahun 2003 Tentang Sistem Pendidikan Nasional. Jakarta: Depdiknas; 2003.

2. Rahmawati, F., \& Arief M. Pengembangan Media E-Learning Teknologi Perkantoran 
Berbasis Schoology Untuk Meningkatkan Literasi Teknologi Informasi dan Komunikasi (TIK) Peserta Didik. Pendidik Adm Perkantoran Univ Negeri Malang. 2019;45-63.

3. Abidin. Desain Sitem Pembelajaran dalam Konteks Kurikulum 2013. Bandung: Refika Aditama; 2014.

4. Mahanal S. Peran Guru Dalam Melahirkan Generasi Emas Dengan. Semin Nas Pendidik HMPS Pendidik Biol FKIP Univ Halu Oleo. 2014;1(September):1-16.

5. Redhana IW. Mengembangkan Keterampilan Abad Ke-21 Dalam Pembelajaran Kimia. J Inov Pendidik Kim. 2019;13(1).

6. Zubaidah S. Keterampilan Abad Ke-21: Keterampilan Yang Diajarkan Melalui Pembelajaran. Semin Nas Pendidik dengan tema "Isu-isu Strateg Pembelajaran MIPA Abad 21. 2017;

7. Astini NKS. PENTINGNYA LITERASI TEKNOLOGI INFORMASI DAN KOMUNIKASI BAGI GURU SEKOLAH DASAR UNTUK MENYIAPKAN GENERASI MILENIAL. In: Prosiding Seminar Nasional Dharma Acarya ke-1 Tantangan dan Peluang Dunia Pendidikan di Era 40. 2019.

8. Iqbal, M. S., Koeshandayanto, S. \& S. Eksplorasi Literasi Teknologi Informasi dan Komunikasi Siswa melalui Blended Learning Fisika. Jurnal Pendidikan:Teori.Penelitian, dan Pengembangan. 2019; Volume 4 N:79-85.

9. Dewi M. KEBUTUHAN PENGEMBANGAN MODUL BIMBINGAN TEKNOLOGI INFORMASI DAN KOMUNIKASI (TIK) TERINTEGRASI LITERASI BARU ERA REVOLUSI INDUSTRI 4.0. J PTI (PENDIDIKAN DAN Teknol INFORMASI) Fak Kegur ILMU Pendidik Univ PUTRA Indones "YPTK" PADANG. 2019;

10. Wilson S, Lydiah N, Pachomius W. Gender Differences in Pedagogical Interaction of Information Communication Technology Among Science and Mathematics Teachers in Public Secondary Schools in Kieni West Subcounty, Nyeri County, Kenya. Int J Educ Res. 2015;3(1):443-62.

11. Sawarsono. Pengantar Psikologi Umum. Jakarta: Rajawali Press; 2013.

12. Zainal R. Kepemimpinan dan Perilaku Organisasi. Jakarta: Rajawali Press; 2017.

13. Kuswana W. Taksonomi Berpikir. Bandung: PT. Remaja Rosdakarya; 2013.

14. Rafianti I, Anriani N, Iskandar K. Pengembangan Perangkat Pembelajaran Matematika Dalam Mendukung Kemampuan Abad 21. KALAMATIKA J Pendidik Mat. 2018;3(2):12338.

15. Sugiyono. Metode Penelitian \& Pengembangan. Bandung: ALFABETA; 2010. 